\title{
The identity (re)construction of nonnative English teachers stepping into native Turkish teachers' shoes
}

\section{Sevcan Mutlu \& Deniz Ortaçtepe}

To cite this article: Sevcan Mutlu \& Deniz Ortaçtepe (2016) The identity (re)construction of nonnative English teachers stepping into native Turkish teachers' shoes, Language and Intercultural Communication, 16:4, 552-569, DOI: 10.1080/14708477.2016.1194852

To link to this article: https://doi.org/10.1080/14708477.2016.1194852

曲 Published online: 21 Jun 2016.

Submit your article to this journal $\widetilde{ }$

Џ Article views: 276

Q View related articles $\widetilde{ }$

View Crossmark data $\asymp$ 


\title{
The identity (re)construction of nonnative English teachers stepping into native Turkish teachers' shoes
}

\author{
Sevcan Mutlu $\mathrm{u}^{\mathrm{a}}$ and Deniz Ortaçtepe ${ }^{\mathrm{b}}$ \\ ${ }^{\mathrm{a} S}$ School of Foreign Languages, Middle East Technical University, Ankara, Turkey; ${ }^{\mathrm{b}} \mathrm{MA}$ TEFL Program, Bilkent \\ University, Ankara, Turkey
}

\section{ABSTRACT}

The present study explored the identity (re)construction of five nonnative English teachers who went to the USA on a prestigious scholarship for one year to teach their native language, Turkish. In that sense, it investigated how this shift from being a nonnative English teacher to a native Turkish teacher influenced their selfimage, self-efficacy, and beliefs about teaching/learning. The data were collected mainly through three different instruments: a personal data questionnaire, ongoing controlled journals along with follow-up questions, and interviews. All the qualitative data were first analyzed according to Boyatzis' [(1998). Transforming qualitative information: Thematic analysis and code development. Sage) thematic analysis, and then the emerging themes were related to three sensitizing concepts, which were (a) self-image, (b) self-efficacy, and (c) beliefs about teaching and learning. The findings revealed that (a) the participating teachers in this study had high(er) self-efficacy but low(er) self-image when teaching English compared to Turkish because of their idealization of native speaker norms; (b) their multiple identities were interacting with each other, and shifting from being a native to a nonnative, and a language teacher to a language user; and (c) their beliefs about teaching and learning coming from their core identity as an English language teacher worked as a catalyst in this process.

Bu çalışma, ana dili İngilizce olmayan İngilizce öğretmenlerinin ana dilleri Türkçe'yi öğretme rolüne geçmesinin, kendilerini algılamaları, yeteneklerine bakış açıları, ve öğretme ve öğrenme ile ilgili düşünceleri açısından kimliklerini yapılandırmalarını nasıl etkilediğini araştırmaktadır. Bu bağlamda, bir burs aracılığıyla bir yıllığına Amerika'ya ana dilleri Türkçe'yi öğretmeye giden beş tane ana dilleri İngilizce olmayan İngilizce öğretmeninin tecrübelerini incelenmiş̧tir. Veriler kişisel bilgi anketi, ek sorularla beraber düzenli olarak gönderilen günlükler ve sözlü mülakatlarla toplanmıştır. Bütün nitel bulgular Boyatzis'in tematik analizine göre çözümlenmiş ve daha sonrasında üç kavramla (kendilerini algılama şekilleri, yeteneklerine bakış açıları ve öğretme ve öğrenme ile ilgili düşünceleri) eşleştirilmiştir. Çalışmanın bulguları göstermiştir ki; a) ana dilini öğretmek katılımcıların kendilerini algılama şekillerine katkıda bulunmuştur, b) İngiliz Dili Öğretimi'nde eğitim almış olmak ve İngilizce öğretmede tecrübeli olmak katılımcıların öğretme yeteneklerini algılamalarında etkili

\section{KEYWORDS}

Teacher identity; self-image; self-efficacy; beliefs about teaching and learning 
olmuştur, c) katılımcılar bir dili ana dili olarak konuşmayı dil öğretimi için yeterli görmemiştir, ve d) öğrenciler, meslektaşlar ve sosyalleşme süreci öğretmenin kimliği üzerinde etkilidir. Bu çalışma mevcut literatürü şu açılardan desteklemiştir; a) öğretmen kimliği çeşitli ve değişken bir yapıya sahiptir, ve b) öğretmen kimliği kendi ile çatışma ve sürekli değişim içindedir. Aynı zamanda, İngilizce öğretmeni olarak yetiştirilmelerinin katılımcıların kimliklerini şekillendirdiği ve katılımcıların kimliklerinin İngiliz dili öğretimine daha fazla dayandığı sonuçlarına varılmıştır.

\section{Introduction}

A considerable amount of research has been conducted on the multiple identities language teachers take on (e.g. Beauchamp \& Thomas, 2009; Varghese, Morgan, Johnston, \& Johnson, 2005); the developmental processes of teacher identity construction (e.g. Clarke, 2008; Kanno \& Stuart, 2011; Tsui, 2007); and the factors affecting teacher identity (e.g. Beauchamp \& Thomas, 2009; Duru, 2006; Olsen, 2010). Among these factors, the distinction between native English-speaking teachers (NESTs) and nonnative English-speaking teachers (NNESTs) has attracted a great deal of interest with more emphasis being placed on NNESTs (e.g. Huang, 2014; Medgyes, 1992; Park, 2012; Pavlenko, 2003). While fewer studies were conducted on the identity construction of NESTs working in English as a foreign/second language (EFL/ESL) settings (e.g. Juhász, 2011), the literature does not provide information about nonnative English teachers who go to English-speaking countries to teach their native tongues, and thus, shift their identities from nonnative to native speaker teachers.

An international educational exchange program sponsored by the US government provides English language teachers in different countries with the opportunity to go to the USA to teach their native language. The purpose of this program is twofold, in the sense that it, first, aims to contribute to higher education institutions in the USA, and second, to provide opportunities for intercultural experience for those to be teaching their native language in the USA. Thus, in this case study, we explored the experiences of five Turkish EFL teachers who were in the USA to teach Turkish for one year. In other words, we investigated how the shift from the role of a nonnative English teacher to a native Turkish teacher affected their identity (re)construction.

\section{Teacher identity}

Regarding the essential role of the teacher in language teaching and learning processes, many researchers have started to explore the concept of teacher identity (e.g. Akkerman \& Meijer, 2011; Beauchamp \& Thomas, 2009; Duru, 2006). As Varghese et al. (2005) put it,

In order to understand language teaching and learning, we need to understand teachers; and in order to understand teachers, we need to have a clearer sense of who they are: the professional, cultural, political, and individual identities which they claim or which are assigned to them. (p. 22) 
While there is no clear-cut definition of the concept of teacher identity (Beijaard, Meijer, \& Verloop, 2004), many researchers have come to an agreement on some key features, one of which is its dynamic nature (e.g. Beauchamp \& Thomas, 2009; Beijaard et al., 2004; Duff \& Uchida, 1997; Duru, 2006; Tang, 1997). According to an overview provided by Day, Kington, Stobart, and Sammons (2006), initial views which perceived teacher identity as a fixed and singular concept unaffected by context have evolved into different notions. Instead, identity construction in general and teacher identity per se are a social process involving constantly changing sub-identities in accordance with different social, cultural, and political contexts and a myriad of relationships (e.g. Akkerman \& Meijer, 2011; Beijaard et al., 2004; Block, 2013; Varghese et al., 2005). On the other hand, based on a review of the literature on teacher identity, Akkerman and Meijer (2011) take a more balanced stance and redefine teacher identity as 'simultaneously unitary and multiple, continuous and discontinuous, and individual and social' (p. 315). By combining contradictory characteristics, this stance shows how complex and blurry the concept of teacher identity is due to different conceptualizations.

Existing studies on teacher identity have opened the way to gain better insights into the essential components of the concept (e.g. Bandura, 1995; Knowles, 1992; Olsen, 2008; Williams \& Burden, 1997). Teachers perceive their professional identity by considering their knowledge of the subject matter they teach, their ability to communicate with learners, and the training they have in order to prepare and execute lessons (Beijaard, Verloop, \& Vermunt, 2000). Kelchtermans (1993) lists self-image, self-esteem, job motivation, task perception, and future perspective as some of the indicators of professional identity; however, he also notes how interwoven these concepts are. Some other components of teacher identity acknowledged by the researchers are self-efficacy (Bandura, 1995; Gibbs, 2003), beliefs about teaching and learning (Williams \& Burden, 1997), knowledge (Beijaard et al., 2004), values, motivation, job satisfaction, commitment (Day et al., 2006), and emotions (Beauchamp \& Thomas, 2009; Day et al., 2006). In the following sections, we will be focusing on self-image, self-efficacy, and teachers' beliefs about teaching and learning which are some of the components that have been widely studied in regard to teacher identity (e.g. Bandura, 1995; Kelchtermans, 1993; Knowles, 1992; Williams \& Burden, 1997).

\section{Self-image}

According to Knowles (1992), teacher identity is 'the way in which individuals think about themselves as teachers - the images they have of self-as-teacher' (p. 99). This definition introduces self-image as one of the components of teacher identity. Selfimage can simply be defined as 'the particular view that we have of ourselves' (Williams \& Burden, 1997, p. 97). Referring to self-image as one of the indicators of teacher identity, Kelchtermans (1993) defines the term as teachers' self-description of themselves and their views of how they are perceived by other people. This point of view brings forward a different stance toward self-image because it refers to teachers' understanding of how others perceive and/or position them as well as their own perceptions and/or positionings of the self. In other words, teachers negotiate their selfimage through their own views of themselves and the images that they believe others ascribe to them. 


\section{Self-efficacy}

According to Williams and Burden (1997), self-efficacy is 'our beliefs about our capabilities in certain areas or related to certain tasks' (p. 97). One of the primary sources of information on self-efficacy is Bandura (1995) who defines the term as 'beliefs in one's capabilities to organize and execute the courses of action required to manage prospective situations' (p. 2). According to Bandura (1995), teachers who trust their abilities have higher motivation to promote learning in class. In contrast, if people have doubts about their capabilities, they experience more stress and tension and give up more easily under difficult conditions. Therefore, teachers who doubt their abilities may have lower levels of motivation and occupational commitment, experience emotional problems, and even end up with teacher burnout (Bandura, 1995).

The difference between self-image and self-efficacy is explained by Zimmerman (1995) who suggests that self-efficacy is related to people's 'judgments of [their] capabilities to perform activities ... not who they are as people or how they feel about themselves in general' (p. 203). Although self-image and self-efficacy might seem to be overlapping, self-image is more related to how individuals describe themselves and their views of how others describe them. Self-efficacy, on the other hand, is people's perceptions of their abilities. More specifically, when teachers describe themselves as approachable, friendly, and enthusiastic, they reflect on their self-images. Teachers' beliefs about their classroom management skills, instructional strategies, and proficiency levels are more related to their capabilities as teachers, and thus are reflections of their self-efficacies.

\section{Beliefs about teaching and learning}

Another crucial element of teacher identity is their beliefs about teaching and learning (Williams \& Burden, 1997). Teachers' approach to the way a language is learned, choice of activities, relationship with students, decisions about techniques for error correction, and many other aspects can be considered as part of teachers' beliefs about teaching and learning. Teachers determine the organization of their lessons, plan their lessons, and react to the problems in class based on these beliefs. In short, teachers' beliefs about teaching and learning affect all their actions and performance in the class (Williams \& Burden, 1997).

There are many internal and external factors affecting a teacher's self-image, self-efficacy, and beliefs about teaching and learning. Olsen (2008) identifies prior personal and professional experience, teacher education experience, current teaching context, and career plans as some of the factors that are influential in the process of teachers' ongoing identity construction. In his book, Olsen (2010) further analyzes teacher identity and lists upbringing, beliefs, opinions, friends, and media as some other factors affecting identity. Moreover, the school environment, learners, colleagues, and school administrators can shape teacher identity (Beauchamp \& Thomas, 2009; Duru, 2006). More specifically, as teachers meet different types of students, interact with their colleagues and administrators within a variety of educational contexts, and participate in teacher education programs, their identities are shaped and reshaped (Beauchamp \& Thomas, 2009).

One factor that may affect teacher identity is being a native or a nonnative speaker of the language taught. The literature has provided different definitions of a native and a nonnative speaker (e.g. Braine, 2010; Davies, 2003; Medgyes, 2001). A native speaker of 
English has been defined as 'someone who speaks English as his or her native language, also called mother tongue, first language, or L1' (Medgyes, 2001, p. 430) and as someone who has the intuitive knowledge about what is accurate and what is not in his or her language (Davies, 2003). In contrast, a nonnative speaker can be defined as a person who learns a language 'as a second or foreign language' (Braine, 2010, p. 9).

The pedagogical advantages of both native and nonnative language teachers have attracted a great deal of attention in the literature (e.g. Medgyes, 1992; Phillipson, 1992). There have also been studies looking at students' and administrators' attitudes toward NESTs and NNESTs (e.g. Braine, 2010; Chen, 2010; Huang, 2014). Recently, studies have also focused on identities and self-perceptions of NESTs and NNESTs. Most of these studies have examined the identity construction of NNESTs by observing their experiences in EFL/ESL contexts or in English-speaking countries (e.g. Huang, 2014; Park, 2012; Pavlenko, 2003). Fewer studies have been conducted on the identity construction of native English teachers during their experiences in EFL/ESL settings (e.g. Juhász, 2011). While there is one study conducted by Ortaçtepe (2015) exploring the identity negotiation of two NNEST who worked in Turkey, and then went to the USA to pursue their graduate degrees, the literature does not provide information about the identity (re)construction of nonnative English teachers who teach their native language in English-speaking countries.

\section{The present study}

\section{Aim of the study}

According to Block (2013), most of the studies exploring the dynamic, complex relationship between language, identity, and intercultural communication examine the movement of people in current times' (p. 127) as their unit of analysis. Being one of those studies, in this case study we dealt with English language teachers in Turkey who went to the USA to teach Turkish, their native language. Turkey is one of the countries from which English teachers can apply for an international educational exchange program sponsored by the US government which provides them with a platform for intercultural communication in which they negotiate their various identities during their interactions in educational and social contexts. More specifically, when English teachers from Turkey receive this scholarship, they teach their native language, Turkish, for one year at a US university. As a result, these teachers switch their role from NNESTs in Turkey to Turkish teachers in the USA, and go through a process during which they may (re)construct their identities as native speaker teachers. Thus, we investigated how this shift from the role of a nonnative English teacher to a native Turkish teacher affected five Turkish EFL teachers' identity (re)construction in terms of their self-image, self-efficacy, and beliefs about teaching and learning.

\section{Participants}

All participants ( 3 females, 2 males) were from Turkey and were between the ages of 27 and 29 years. Before going to the USA, the participants worked at different universities in Turkey as English teachers, and their experiences ranged from four to seven years. 
None of them had experience in teaching Turkish or a language other than English before going to the USA, except for one participant who had helped a few visually impaired students with their Turkish lessons when she was a university student. The participants went to the USA in mid-August 2014 to teach Turkish and they were scheduled to go back to Turkey in May 2015. To preserve anonymity and confidentiality, the participants were identified by pseudonyms (Ahmet, Berna, Gamze, Merve, and Tamer) throughout the study.

\section{Research design}

In this case study, we adopted qualitative research strategies to collect data by means of three instruments: a personal data questionnaire, ongoing controlled journals along with follow-up questions, and interviews.

Demographic information about the participants was collected with the help of a questionnaire at the beginning of the data collection process. This questionnaire included questions that helped us find out more about the background of the participants. As one of the widely used data collection tools in identity research (e.g. Park, 2012; Pavlenko, 2003; Tsui, 2007), journal entries were used to understand the participants' educational and intercultural experiences in the USA. We preferred controlled journals over spontaneous ones as they provide starting points for the participants to discuss their personal experiences.

According to Pavlenko (2008), personal experience narratives through controlled journals can be collected by providing the participants with key words, interview questions, or requests to tell a particular story related to the phenomenon examined. In our study, the ongoing controlled journals consisted of four simple items questioning a positive and a negative event in their educational and social lives (Appendix 1). We selected these questions for two reasons. First, as Varghese et al. (2005) suggest, teacher identity is both an individual and a social construct which is formed and reformed in social contexts and within individuals' inner worlds. Therefore, through these questions, we aimed to capture the participants' experiences in their teaching practices as well as intercultural exchanges in their social lives that could affect their identity (re)construction. Second, given the limitations of keeping a journal (lack of time, forgetting to write, etc.), we wanted to make sure that the participants had some reference points that would keep them on track in terms of writing their experiences. The participants sent their journals every two weeks via email from late September 2014 to late February 2015, for approximately five months. After the receipt of every journal, the participants were asked follow-up questions based on their journal entries for clarification and elaboration.

Another instrument that was employed in this study was interviews. The interviews were guided by semi-structured questions, which served as a point of departure, but were conducted flexibly depending on the experiences of the participants and what they revealed during the interview (see Appendix 2 for sample interview questions). The questions can be grouped under general questions, and questions related to their self-image, self-efficacy, and beliefs about teaching and learning. The purpose of the general questions was to obtain more in-depth information about the participants' teaching experiences in Turkey and in the USA, their daily lives in the USA, and their expectations of these experiences. The purpose of the other questions was to uncover the participants' descriptions of themselves as teachers, their feelings as nonnative English and native Turkish teachers, the 
challenges they faced, their perceptions of their teaching and language abilities, and their preferences for teaching methods and activities. Two interviews were conducted with each participant. The first interview was carried out in early October 2014, while the second one was in late February 2015. The data collection procedure took place in English as the participants stated being comfortable in both English and Turkish. All interviews were conducted through Skype and were both tape-recorded and video-recorded by using Skype video recorder.

\section{Data analysis}

Data analysis consisted of several steps. Initially, the interviews, which were video- and tape-recorded, were transcribed for data analysis. As the next stage of data analysis, we went over all the qualitative data coming from controlled journals and interview transcripts according to Boyatzis' (1998) thematic analysis. Data-driven (inductive) approach was used in this study as this form of analysis is sensitive to the raw information and increases the validity of the research (Boyatzis, 1998). The stages he suggests for this approach are reducing raw information, identifying themes, comparing themes, creating a code, and determining reliability. Considering this framework, each participant's journals and interview transcripts were read on paper copies rather than on screen because of the ease to notice the details on paper (Seidman, 2006). While reading through the data for the first time, we made comments in the margins of the paper copies to reach naturally emerging themes. During the second round, the data were color coded in an attempt to code the data in a more systematic way.

A further analysis of the data was necessary to relate the themes that emerged in the initial analysis of raw data to sensitizing concepts. Charmaz (2006) describes sensitizing concepts as 'points of departure to form interview questions, to look at data, to listen to interviewees, and to think analytically about the data' (p. 17). The main problem for us was to delve into the core of teacher identity and identify the key components affecting all the others. Looking at previous studies, Beijaard et al. (2004) argue that different concepts regarding teacher identity actually refer to the same thing, noting the need to provide a 'better conceptual clarity' as to how these concepts are related to each other (p. 126). In fact, a careful look at the suggested components of teacher identity in the literature revealed a set of interrelated terms. Thus, based on our review of the literature on teacher identity, we chose self-image, self-efficacy, and beliefs about teaching and learning to help us break the complexities of this concept. We chose these three concepts for three reasons: (a) they were widely referred to as being influential in shaping teacher identity; (b) despite how related they were with each other, it was easy to distinguish them from each other; and (c) they enabled us to approach the data from different perspectives. During this stage, the themes that emerged during color-coding were categorized under these three sensitizing concepts, while paying attention to those which did not fit under any one of them. This way, the procedure of analysis was more open to additional concepts that might have emerged from the data. While the first inductive stage was conducted separately by each researcher who then discussed the emerging themes and codes to see if there were any discrepancies, we conducted the deductive stage with sensitizing concepts together over several meetings.

The physical distance between the researchers (located in Turkey) and the participants (located in the USA) turned out to be an advantage during the data collection and analysis 
stages for two reasons. First, the participants were more comfortable expressing their experiences with someone they did not know. Second, not knowing the participants increased the objectivity of the data analysis process as we were not influenced by their personality or their background, but were able just to concentrate on their current experiences.

\section{Findings}

In this section, we will present the results of data analysis in accordance with the three sensitizing concepts: self-image, self-efficacy, and beliefs about teaching and learning.

\section{The shift in teacher identity in terms of self-image}

The findings revealed changes in the way participants described themselves in their repeats 'new' roles as native Turkish teachers in their new educational and social contexts compared to their roles as nonnative English teachers back in Turkey. To begin with, being in the position of a native teacher gave the participants a sense of confidence as their students did not question their knowledge of Turkish or refute what they said, but showed them respect as they were native speakers. Merve compared the ways she felt as a nonnative English and native Turkish teacher:

When you are a native speaker of a language, there is no way for your students to refute what you have said ... But when it comes to teaching English, there might be times when you're not sure ... especially if you are teaching more advanced levels, you should be more prepared because you might not have the necessary knowledge to talk about certain questions that your students have posed, but here like in teaching your native language, you don't have such fears. (Interview 2)

Ahmet also talked about how 'cool' and 'safe' it was to be a native speaker of a language as his students admired him when he uttered sentences in Turkish. Related to this finding, in a study exploring the perceptions of NESTs while teaching EFL, Juhász (2011) found that native teachers felt safe since it was not the teacher's 'fault or ... lack of knowledge' when students could not understand a topic (p. 95). Similarly, the participants in this study also felt safe and powerful in their new roles. Moreover, comparing their first days in the USA and their experiences after six months, the participants realized that their confidence as a native Turkish teacher increased in time with more teaching experience.

The responsibilities the participants took on as Turkish teachers and their working conditions in the USA also led to some changes in the ways they described themselves as language teachers. To illustrate, during her teaching experience in the USA, Berna implemented communicative language teaching in her class as she did not have to follow a strict syllabus as she used to in Turkey, and she had the freedom to decide how much time to allocate for different topics. This flexibility helped her unlock her creative side and feel more satisfied as a teacher. Taking the responsibility of the entire class seemed to make the participants see how organized, professional, prepared, but also flexible they could be since they were able to design and implement their own lesson plans. As a result, they felt more motivated and successful as teachers in the USA. In that sense, the 
participants' images of themselves changed along with the responsibilities they took on in their new workplace as indicated in their ongoing journals.

The participants' views of how their students and colleagues perceived them as teachers also had effects on their self-images. Students' appreciation and positive feedback encouraged the participants to work more, while at the same time increasing their confidence. One important finding was observed in Ahmet's perception of how his students and colleagues described him. Although in the first interview the only adjective he could find was 'fun' when he was asked about his students' and colleagues' descriptions of him as a teacher, his perception of himself was different during the second one. Being portrayed as a 'very organized and prepared' teacher by his students, Ahmet described himself as a 'more responsible,' 'prepared,' and 'organized' teacher (Interview 2).

The fact that the participants were in a new educational and social context and had contact with different people and lifestyles also affected their self-images. There were also individual gains such as being more open to different people, more patient and tolerant, and more confident while socializing, and dealing with the challenges. For instance, Ahmet and Tamer described themselves as 'more complete' (Interview 2). For Tamer, 'being more complete' meant seeing different lives, worlds, and points of views. Ahmet further explained what he meant by being complete with the words 'more knowledgeable and experienced,' which were also used by Gamze to describe how she felt after her intercultural experiences in the USA.

Duru (2006) and Beauchamp and Thomas (2009) claim that the school environment, institutional characteristics, learners, colleagues, and administrators are some of the factors that may lead teachers to construct new images, and thus affect teacher identity. In this study, being in the position of a native teacher in a different educational setting, taking on different responsibilities and their intercultural experiences in the USA led to changes in the participants' descriptions of themselves as teachers and their views of how their students and colleagues described them.

\section{The shift in teacher identity in terms of self-efficacy}

The results also revealed changes in the participants' perceptions of their teaching abilities both in Turkish and English. First, in their new roles as native Turkish teachers, the participants felt competent in the Turkish culture, which helped them benefit from the culture-related tasks in the class. Nevertheless, they also experienced some challenges such as not being able to explain the rationale behind the grammar rules or simplifying the language. This finding is consistent with Juhász's (2011) study in which the NESTs acknowledged having problems while explaining grammatical rules to students. Similarly, although the participants of the current study had the intuitive knowledge to figure out the grammatical rules of Turkish, this was not enough to explain the rationale behind certain rules. As a teacher of their mother tongue, the participants realized that there were a lot of rules which they used automatically and unconsciously while speaking. For instance, Merve stated that her awareness of Turkish increased, while Tamer was surprised to see the rules he did not know and was not familiar with. Ahmet also stated:

I feel less competent when I teach Turkish but also more confident when they ask me if something sounds good just like we do in Turkey. We ask native speakers if there should be a 'the' 
or not. They look at it and they are like 'ah it sounds better without it.' That's how I answer a lot of questions here right now because that's what you say when you're a native speaker. You don't know all the rules so you just think about how it sounds... The only weakness I have right now about teaching Turkish is that I'm inexperienced. (Interview 1)

While gaining experience in teaching Turkish contributed to the participants' confidence and helped them develop their own strategies, they stressed the importance of being trained in teaching to be equipped with the knowledge and skills to implement different methods and teach a language effectively. Related to the effect of teacher training, Wong (2009) explored eight inexperienced and untrained NESTs' experiences while teaching English to find out their self-perceptions and teaching-related problems. The findings suggested the importance of being trained and gaining experience for NESTs to teach their native language effectively. Similar to what Wong (2009) suggested, comparing their role as nonnative English teachers with that of native Turkish teachers, the participants in the present study all underlined the necessity of teacher education and/or training as they felt more competent as English teachers despite being a native Turkish teacher.

Students' motivation and progress also influenced the participants' perceptions of their teaching abilities. As an example, when Merve observed that her students were able to pick up the structures she frequently used in the class, she felt satisfied to see that she could help her students make progress in such a short time (Journal Entry). Berna even stated that she felt more 'like a teacher' in the USA and she did not mind spending hours preparing lessons. She noted that the techniques she implemented in class were not successful back in Turkey, and she did not want to prepare for the class due to her students' lack of motivation (Interview 1). In a study conducted on student-teachers, Gibbs (2003) argued that teachers' performance increases when they are persuaded that they are capable of and good at what they are doing. The findings of the present study were in line with what Gibbs (2003) suggested because being appreciated by colleagues or students was a source of motivation and confidence for the participants, while negative feedback from students caused them to question their teaching abilities.

The participants also reflected on their strengths and weaknesses as English language users and teachers. One important finding was related to their confidence and competence in teaching. It was pointed out by the participants that factors such as being aware of their own weaknesses in terms of pronunciation and vocabulary, not being able to answer students' questions, and not being equipped with the necessary knowledge to be able to teach about the target language culture caused them to feel insecure, incompetent and uncomfortable when teaching English. Gamze, for instance, said:

Maybe because all the things we have learned so far is on teaching English, I really know how to teach English. Sometimes I can't even use the words. I can't pronounce the words correctly. Still I know which one is the correct one, so I am fully aware of the things. Even while I am making mistakes, I generally know I am making mistakes. (Interview 2)

The present study confirms what Medgyes (2001) pointed out in terms of NNESTs' awareness of their linguistic handicap and lack of competence in teaching culture as the participants in this study reported feeling insecure due to their weaknesses. Notwithstanding, they did not feel inferior as nonnative teachers as Medgyes (2001) suggested. Gamze stated:

Here from time to time I feel less competent about Turkish because this is an area that I haven't been trained. Before coming here, I could have said I wish I were a native teacher, but it's not 
enough ... Here in the class when students ask me a question, sometimes I can't answer their questions and I am a native teacher, but I am not trained in that field. With this background in English language teaching I wish I were a native speaker of English. (Interview 1)

As seen in her comments, despite the fact that Gamze felt more competent in English because of her training, she still wanted to be a native speaker of English. Similarly, Ahmet also stated that '[his] English [was] never gonna be like really native-like' and it was not possible for him to reach the native speaker level despite spending years as a learner and as a teacher of English (Interview 1). Related to this finding, Ortaçtepe (2012) pointed out that Turkish students perceive native speakers as the authority, while Alptekin (2002) noted that NNESTs feel 'intimidated by native speaker norms of use and usage' (p. 62). Parallel to what Ortaçtepe (2012) and Alptekin (2002) suggested, Ahmet's comparison of himself with native speakers of English, and his feelings of disappointment at seeing that being a native speaker was an unattainable goal, confirm the adherence to native speaker norms, especially in EFL contexts such as Turkey.

Lastly, the fact that the participants were aware of their strengths and weaknesses both as Turkish and English teachers draws attention to the role of self-doubt in teachers' lives. In this sense, Wheatley (2002) claims that teachers' doubts about their efficacy can support teacher learning and professional growth. Despite the fact that the literature focuses on the importance of having self-confidence and positive efficacy beliefs, this study shows that self-doubt can also be useful as it might encourage teachers to reflect on their performance, strengths and weaknesses so that they can improve themselves professionally.

\section{The shift in teacher identity in terms of beliefs about teaching and learning}

Being a native speaker was again brought up by the participants in relation to their beliefs about teaching and learning as they all agreed that being a native speaker and knowing a language were not enough to teach a language. For instance, Merve stated:

... when I came here, I realized that OK I am a native speaker of Turkish, but that doesn't mean that I can teach it very well. I mean teaching is totally different. You must be aware of the processes that a student goes through ... I think I feel more confident in teaching English because I was trained in that ... because teaching is different from knowing something. (Interview 1)

Comparing native and nonnative teachers, Medgyes (1992) argued that being more proficient in a language did not mean being an efficient teacher as there were other factors in play - such as experience, age, motivation and training. Parallel to this view, and as already mentioned in the findings related to their self-image and self-efficacy, the participants of this study felt more competent in teaching English, as teaching a language was different from knowing it. Being a native speaker of Turkish, they noticed that they did not know the rules as they had not felt the need to analyze their speech and the reasons for the rules before.

As far as the participants' beliefs about their classroom practices, being a nonnative teacher or a native teacher and teaching English or Turkish did not seem to influence their beliefs regarding teaching styles and practices. This finding conflicts with the results from Juhász (2011), which revealed that NESTs and NNESTs adopted different teaching styles. Unlike Juhász's (2011) study, the participants in this study continued to 
implement the methods that they used back in Turkey when they were teaching Turkish in the USA, except for Tamer, who observed that traditional teaching methods could also be used quite effectively. He added:

I saw that post-method pedagogy is working actually and it's very useful. You don't have to necessarily use communicative language teaching method. Not just that method, but you can do whatever you want as long as it serves the purpose, so that made me relaxed ... and I feel more confident in terms of methodology. (Interview 2)

While the results showed similarities in terms of their reported teaching practices in Turkish and English, there was a slight change in their realization of how important it is to integrate the target language culture into their classes. Reflecting on their teaching practices back in Turkey, the participants reported that they did not allocate enough time for intercultural activities due to time constraints as well as their lack of confidence and competence in the target language culture. While teaching Turkish in the USA, however, they had enough time to incorporate culture into class as they designed their own courses, and they realized how engaged and motivated the students were when they were introduced to the Turkish culture. These findings confirm Ortaçtepe's (2015) study that EFL teachers in Turkey were limited by the institutions and curricula even though they wanted to foster their learners' intercultural competence.

On a related note, the participants' socialization in the States also influenced their views on the role of culture in language classes. Ahmet claimed that he gained 'more command on the American culture' thanks to this experience, thus he had more to share with his students about 'the American culture and cross-cultural issues' when he went back to Turkey to teach English. This finding is consistent with Ortaçtepe's (2015) study which found that the participants' social experiences in the USA resulted in changes in their teacher identities in terms of how they would teach English when they go back to Turkey.

There was also change in the participants' beliefs about the use of target language in their classes. The accessibility of Turkish in the USA and attitudes toward the use of target language there influenced their beliefs regarding this issue and their practices. Ahmet, for instance, stated:

Our beginner level students in Turkey are more exposed to English than these people will ever be exposed to Turkish because English is out there, it's so accessible ... Turkish is not like that. That's why, I sometimes need to speak English more often than I'd like to ... I feel like I should explain how it works in English just to make sure. (Interview 1)

Comparing the theory and practice in terms of the use of the target language in the class, Tamer argued that there was 'hypocrisy in terms of their demands in teaching English to NNES [Nonnative English Speaking] countries and their actual practices here [in the US] in teaching foreign languages.' Although 'the modern teaching methods all suggest[ed] exposure to target language as much as possible,' his students complained when he used the target language and the instructors teaching other languages also used the first language while teaching (Journal Entry). In short, the fact that the teachers witnessed different attitudes toward the use of the target language in class influenced their beliefs regarding this issue.

The participants also made comments on the sources of learner motivation by drawing from their experiences back in Turkey and in the USA. For Gamze, the key to promoting 
student motivation was through caring for the students and being approachable for them, while Merve concluded that students would not be able to learn a language unless they really wanted it and that some people were more talented to learn a language. She stated:

I have realized that motivation is the big step that you have to have to learn a language. So even if it is Turkish or Chinese or English or something else, if you really don't want to learn, you can't learn it, so here I have realized although Turkish is a very difficult language to learn for me, I have realized once you are motivated to learn it, you definitely learn it in a way, but that shouldn't mean that motivation is the only tool that you need to learn a language. (Interview 2)

Overall, the findings indicated that there were changes in the participants' beliefs about being a native speaker and being trained in a language. More specifically, they concluded that being a native speaker was not enough to be able teach a language, and being trained in language teaching was more important than being a native or a nonnative teacher. In fact, having a background in teaching English seemed to affect the participants' teaching performance in teaching another language as the participants' beliefs about the methods and their classroom performances did not show major changes, except for the use of the target language in class, and the role of culture in language teaching. Having different types of students and teaching a different language, the participants also reconsidered their beliefs about Turkish language, and student motivation to learn a language. All in all, the findings confirmed that teachers' beliefs about teaching and learning were influenced by their changing roles from nonnative English teachers in Turkey to native Turkish teachers in the USA.

\section{Discussion and conclusion}

According to Byram and Fleming (1998), the intersection of the notions of identity and interaction is the starting point for understanding the concept of intercultural communication, as it is through interaction with others that people negotiate their identities. Thus, in this case study we investigated how the shift from the role of a nonnative English teacher to a native Turkish teacher affected teacher identity (re)construction by exploring the intercultural experiences of five nonnative English teachers who went to the USA on a prestigious scholarship for one year to teach their native language. The findings of the study contribute to the literature in regard to the following issues: the shifting nature of teacher identity in regard to socially situated and core identities, and the native speaker versus nonnative speaker dichotomy.

By altering the participants' roles from being a nonnative English teacher to a native Turkish teacher, the educational exchange program enabled them to (re)negotiate their teacher identity as reflected in the changes observed in their self-image, self-efficacy, and beliefs about teaching and learning. More specifically, the findings revealed shifts in terms of the way the participants described themselves, their confidence and competence, their perceptions of their abilities as teachers/users of both languages, their views of how their students and colleagues perceived them, and their beliefs about teaching and learning. In that sense, the findings confirm that teacher identity is multiple and has a shifting nature as suggested in the literature (e.g. Beijaard et al., 2004; Norton Peirce, 1995; Varghese et al., 2005). Gee's (1999) distinction between 'socially situated' and 'core' identities is relevant for the findings of this study, as with their new teaching practices (e.g. teaching 
Turkish, new workplace, and burgeoning relationships with colleagues and students) and contexts (e.g. their intercultural exchanges and socialization practices in the USA), the participating teachers shifted their core identity as a nonnative teacher to a native one. The results showed that their English teacher identities blended in with their Turkish teacher identities since they made use of their past experiences while teaching Turkish in the USA, and reflected on how they would use their newly learned experiences while teaching English back in Turkey. Even when they were not teaching but socializing, they were looking for activities or experiences that could benefit their classroom practices in Turkey. Therefore, their multiple identities were interacting with each other, and moving back and forth from being a native to a nonnative, and a language teacher to a language user. Their beliefs about teaching and learning coming from their core identities as English language teachers also worked as a catalyst in this process of shifting from their core identities to socially situated identities, and vice versa. In that sense, this study confirms that teacher identity is not fixed, but shifting, multiple, and blurred (Faez, 2011; Norton, 1997; Norton Peirce, 1995; Ochs, 1993; Ortaçtepe, 2015; Toohey \& Norton, 2010; Varghese et al., 2005).

As regards the conflicting results in the participants' self-image and self-efficacy in relation to the issue of native speaker versus nonnative speaker dichotomy, the findings concur with the previous studies suggesting that teacher identity is in conflict and flux (Ochs, 1993; Ortaçtepe, 2015). More specifically, being a native Turkish teacher led the participants to describe themselves as more confident, safe, and powerful in class, while they were more competent in terms of their teaching abilities in the position of a nonnative English teacher. In other words, being a native teacher was influential in their self-image as the way participants positioned themselves and were positioned by their students changed when they stepped into the shoes of a native teacher. As for their self-efficacy, despite their claimed weaknesses in pronunciation or the knowledge of the American culture, the participants felt more competent while teaching English since they were trained in English language teaching and they were experienced in teaching English. Being a native speaker was not seen as a privilege, although it had its own merits of having the intuitive and sociocultural knowledge of the language. This finding was supported by the participants' beliefs about teaching and learning as well, as they reported that being a native speaker and knowing a language were not enough to be able to teach a language, and teaching was different from knowing a language. Therefore, it can be concluded that being a native speaker can lead to a positive self-image, but training and experience are more influential in teacher efficacy. According to Beijaard et al. (2000), teachers construct their identities from 'the ways they see themselves as subject matter experts, pedagogical experts, and didactical experts' (p. 751). Based on this argument, the results of this study suggest that self-efficacy is a concept more related to teachers' core identity influencing teaching practices, as opposed to self-image contributing to their socially situated identities.

According to Day et al. (2006), teachers build their identities in light of their self-image regarding the characteristics of the ideal teacher they wish to be. In that sense, another interesting finding of this study was related to how the participating teachers still felt the need to be native-like, despite the fact that they were already trained in English language teaching and noticed the significance of training when they became native speakers themselves. In other words, the participating teachers in this study had high(er) selfefficacy but low(er) self-image when teaching English compared to Turkish because of 
their idealization of native speaker norms. This finding draws attention to the way preservice teacher education programs in Turkey still idealize native speaker norms. For instance, in Atay's (2005) study, Turkish prospective teachers of English regarded having native-like competence as the main purpose of English language teaching, and reported that having a native teacher is more advantageous in order to develop a native-like accent. From a different perspective, exploring English language teacher education programs in Turkey, Cepik and Polat (2014) claimed that teacher educators expect teachers to have near-native proficiency in English. Confirming the results of Atay (2005) and Cepik and Polat's (2014) research, this study highlights the fact that that native speaker norms are still influential in the pre-service education programs in Turkey.

One limitation of this study resulted from the physical distance between the researchers and the participants. We had to employ online data collection instruments through email journals and Skype interviews, which allowed us no chance to physically meet the participants and establish more rapport. The time difference between Turkey and the USA also contributed to limitations as we had to restrict the number of interviews to two due to scheduling problems. We could not conduct any classroom observations of their actual teaching practices in the States as Turkish teachers, which could have also helped understand their teaching behavior, and enabled data triangulation. Thus, a follow-up study can be conducted on the same participants to see the effects of their one year experience in the States on their identity (re)construction and classroom practices as nonnative English teachers back in Turkey. Such a follow up study would respond to Pavlenko's (2003) call 'to examine the long-term impact of discourses and identity options on social and discursive realities in and outside teachers' language classrooms' (p. 266). More specifically, the intercultural contexts they create in their language classrooms, as well as how the changes they mentioned with regard to their self-efficacy, self-image, and beliefs about language learning and teaching, are reflected in their actual classroom practice and would shed more light on the long-term effects of their educational and intercultural experiences in the USA.

Lastly, the findings of this study might benefit future English language teaching practices and contribute to the discussion on the native and nonnative dichotomy. The findings suggest that being a native teacher is not enough to be able to teach a language, but training is the core of effective teaching. Given that teacher identity is greatly influenced by training, this study calls for particular attention to teacher training in language teaching programs, irrespective of whether one is a native or a nonnative teacher. Hence, administrators and trainers can work more on the training programs to equip the teachers with the necessary knowledge, methodology, and teaching skills so that they can handle the different responsibilities they take on while teaching another language.

\section{Disclosure statement}

No potential conflict of interest was reported by the authors.

\section{Notes on contributors}

Sevcan Mutlu received her BA and MA degrees at Middle East Technical University and Bilkent University, respectively. She is currently teaching English as an instructor at Middle East Technical University. Her research interests are teacher identity and intercultural communication. 
Dr Deniz Ortaçtepe completed her BA (in ELT) and MA degrees (in Educational Sciences) at Bogazici University, Turkey. After receiving her doctorate degree in Curriculum and Instruction at the State University of New York, Albany, she started working as an assistant professor in the MA TEFL Program at Bilkent University, Turkey. Her research interests are second language socialization, intercultural pragmatics, and sociolinguistics.

\section{References}

Akkerman, S. F., \& Meijer, P. C. (2011). A dialogical approach to conceptualizing teacher identity. Teaching and Teacher Education, 27, 308-319. doi:10.1016/j.tate.2010.08.013

Alptekin, C. (2002). Towards intercultural communicative competence in ELT. ELT Journal, 56(1), 57-64. doi:10.1093/elt/56.1.57

Atay, D. (2005). Reflections on the cultural dimensions of language teaching. Language and Intercultural Communication, 5(3\&4), 222-236. doi:10.1080/14708470508668897

Bandura, A. (1995). Exercise of personal and collective efficacy in changing societies. In A. Bandura (Ed.), Self-efficacy in changing societies (pp. 1-45). Cambridge: Cambridge University Press.

Beauchamp, C., \& Thomas, L. (2009). Understanding teacher identity: An overview of issues in the literature and implications for teacher education. Cambridge Journal of Education, 39(2), 175189. doi:10.1080/03057640902902252

Beijaard, D., Meijer, P., \& Verloop, N. (2004). Reconsidering research on teachers' professional identity. Teaching and Teacher Education, 20, 107-128. doi:10.1016/j.tate.2003.07.001

Beijaard, D., Verloop, N., \& Vermunt, J. D. (2000). Teachers' perceptions of professional identity: An exploratory study from a personal knowledge perspective. Teaching and Teacher Education, 16, 749-764.

Block, D. (2013). The structure and agency dilemma in identity and intercultural communication research. Language and Intercultural Communication, 13(2), 126-147.

Boyatzis, R. E. (1998). Transforming qualitative information: Thematic analysis and code development. Thousand Oaks, CA: Sage.

Braine, G. (2010). Nonnative speaker English teachers: Research, pedagogy, and professional growth. New York, NY: Routledge.

Byram, M. \& Fleming, M. (Eds.). (1998). Language learning in intercultural perspective. Cambridge: Cambridge University Press.

Cepik, S., \& Polat, N. (2014). Mandates, needs, equitable resources, and current research in English language teacher education: The case of Turkey. International Journal of Research Studies in Education, 3(2), 83-96. doi:10.5861/ijrse.2014.642

Charmaz, K. (2006). Constructing grounded theory: A practical guide through qualitative analysis. London: Cromwell Press.

Chen, X. (2010). Identity construction and negotiation within and across school communities: The case of one English-as-a-new-language student (ENL) student. Journal of Language, Identity and Education, 9(3), 163-179. doi:10.1080/15348458.2010.486274

Clarke, M. (2008). Language teacher identities: Co-constructing discourse and community. Clevedon, UK: Multilingual Matters.

Davies, A. (2003). The native speaker: Myth and reality. Clevedon: Cromwell Press.

Day, C., Kington, A., Stobart, G., \& Sammons, P. (2006). The personal and professional selves of teachers: stable and unstable identities. British Educational Research Journal, 32(4), 601-616. doi:10.1080/01411920600775316

Duff, P. A., \& Uchida, Y. (1997). The negotiation of teachers' sociocultural identities and practices in postsecondary EFL classrooms. TESOL Quarterly, 31(3), 451-486.

Duru, S. (2006). The influences on teacher identity and the suggestions for the new teacher identities. Eurasian Journal of Educational Research, 22, 121-131.

Faez, F. (2011). Reconceptualizing the native/nonnative speaker dichotomy. Journal of Language, Identity \& Education, 10(4), 231-249. doi:10.1080/15348458.2011.598127

Gee, J. P. (1999). Introduction to discourse analysis: Theory and method. London: Routledge. 
Gibbs, C. (2003). Explaining effective teaching: Self-efficacy and thought control of action. Journal of Educational Enquiry, 4, 1-14. doi:10.1.1.113.2245

Huang, I. (2014). Contextualizing teacher identity of non-native-English speakers in US secondary ESL classrooms: A Bakhtinian perspective. Linguistics and Education, 25, 119-128. doi:10.1016/j. linged.2013.09.011

Juhász, A. (2011). Native EFL teachers' self-perception of their teaching behaviour: A qualitative study. WoPaLP, 5, 86-99.

Kanno, Y., \& Stuart, C. (2011). Learning to become a second language teacher: Identities-in-practice. The Modern Language Journal, 95, 236-252.

Kelchtermans, G. (1993). Getting the story, understanding the lives: from career stories to teachers' professional development. Teaching and Teacher Education, 9(5/6), 443-456. doi:10.1016/0742051X(93)90029-G

Knowles, J. G. (1992). Models for understanding pre-service and beginning teachers' biographies: Illustrations from case studies. In I. F. Goodson (Ed.), Studying teachers' lives (pp. 99-152). London: Routledge.

Medgyes, P. (1992). Native or non-native: Who's worth more? ELT Journal, 46, 340-349. doi:10. 1093/elt/46.4.340

Medgyes, P. (2001). When the teacher is a non-native speaker. In M. Celce-Murcia (Ed.), Teaching English as a second or foreign language (pp. 429-442). Boston, MA: Heinle \& Heinle.

Norton, B. (1997). Language, identity and the ownership of English. TESOL Quarterly, 31(3), 409429. doi:10.2307/3587831

Norton Peirce, B. (1995). Social identity, investment, and language learning. TESOL Quarterly, 29 (1), 9-31. Retrieved from http://www.jstor.org/stable/3587803

Ochs, E. (1993). Constructing social identity: A language socialization perspective. Research on Language and Social Interaction, 26(3), 287-306.

Olsen, B. (2008). How reasons for entry into the profession illuminate teacher identity development. Teacher Education Quarterly, 35, 23-40.

Olsen, B. (2010). Teaching for success: Developing your teacher identity in today's classroom. Boulder, CO: Paradigm Publishers.

Ortaçtepe, D. (2012). The development of conceptual socialization in international students: A language socialization perspective on conceptual fluency and social identity. Newcastle upon Tyne: Cambridge Scholars Publishing.

Ortaçtepe, D. (2015). EFL teachers' identity (re)construction as teachers of intercultural competence: A language socialization approach. Journal of Language, Identity and Education, 14(2), 96-112.

Park, G. (2012). 'I am never afraid of being recognized as an NNES': One teacher's journey in claiming and embracing her nonnative-speaker identity. TESOL Quarterly, 46(1), 127-152. doi:10. $1002 /$ tesq.4

Pavlenko, A. (2003). 'I never knew I was a bilingual': Reimagining teacher identities in TESOL. Journal of Language, Identity and Education, 2(4), 251-268. doi:10.1207/S15327701JLIE0204_2

Pavlenko, A. (2008). Narrative analysis in the study of bi- and multilingualism. In M. Moyer \& L. Wei (Eds.), The Blackwell guide to research methods in bilingualism (pp. 311-325). Oxford: Blackwell.

Phillipson, R. (1992). Linguistic imperialism. Oxford: Oxford University Press.

Seidman, I. E. (2006). Interviewing as qualitative research: A guide for researchers in education and the social sciences (3rd ed.). New York, NY: Teacher College Press.

Tang, C. (1997). The identity of the nonnative ESL teacher on the power and status of non-native ESL teachers. TESOL Quarterly, 31(3), 577-580. doi:10.2307/3587840

Toohey, K., \& Norton, B. (2010). Language learner identities and sociocultural worlds. In R. B. Kaplan (Ed.), The Oxford handbook of applied linguistics (2nd ed., pp. 178-189). New York, NY: Oxford University Press.

Tsui, A. (2007). Complexities of identity formation: A narrative inquiry of an EFL teacher. TESOL Quarterly, 41(4), 657-680. 
Varghese, M. M., Morgan, B., Johnston, B., \& Johnson, K. A. (2005). Theorizing language teacher identity: Three perspectives and beyond. Journal of Language, Identity \& Education, 4, 21-44. doi:10.1207/s15327701jlie0401_2

Wheatley, K. F. (2002). The potential benefits of teacher efficacy doubts for educational reform. Teaching and Teacher Education, 18(1), 5-22. doi:10.1016/S0742-051X(01)00047-6

Williams, M., \& Burden, R. L. (1997). Psychology for language teachers: A social constructivist approach. Cambridge: Cambridge University Press.

Wong, C. (2009). Are native speakers 'good' language instructors? A case study of untrained ESL tutors. ARECLS, 6, 122-140.

Zimmerman, B. J. (1995). Self-efficacy and educational development. In A. Bandura (Ed.), Self-efficacy in changing societies (pp. 202-231). New York, NY: Cambridge University Press.

\section{Appendix 1. Controlled journals}

Thinking of your experiences there...

1. Tell us a positive event in your social life.

2. Tell us a negative event in your social life.

3. Tell us a positive event in your teaching.

4. Tell us a negative event in your teaching.

\section{Appendix 2.}

Sample interview questions asked in both the first and the second interview

1. Can you give some information about your present working conditions? Your daily life?

2. How do you describe yourself as a teacher?

3. How others describe you as a teacher?

4. As an English teacher, how do you feel in terms of your own strengths and weaknesses?

5. As a Turkish teacher, how do you feel in terms of your own strengths and weaknesses?

6. How do you evaluate your language ability?

7. How do you evaluate your teaching ability (skills and knowledge in Turkish/English)?

8. How are your teaching practices in the USA similar to or different from your teaching practices in Turkey? 